UDC 604:628.4

LBC 40.40

\title{
COMPARISON OF TECHNOLOGIES FOR BROOD PROCESSING
}

\author{
Aleksey V. Sklyar \\ Big Dutchman Ltd., Moscow, Russian Federation \\ Nikolay G. Bashkirtsev \\ Sheksninskaya Poultry Farm, Sheksna Village, Vologda Region, Russian Federation \\ Sergey A. Chistyakov \\ Sheksninskaya Poultry Farm, Sheksna Village, Vologda Region, Russian Federation \\ Margarita V. Postnova \\ Volgograd State University, Volgograd, Russian Federation
}

\begin{abstract}
An analysis of the work of poultry farms for the processing of manure shows that the technological reason lies in the complex of objective shortcomings of the methods currently used. The article shows that modern methods of energy recovery of litter and all alternative methods of producing biofertilizers from the raw material with the technology of intensified thermophilia are not inferior to all existing ones in anything, at capital intensity and operational costs, and surpasses the alternative group in times, and energy methods by an order of magnitude.

Key words: poultry farms, brood.
\end{abstract}

УДК 604:628.4

ББК 40.40

СРАВНЕНИЕ ТЕХНОЛОГИЙ ПЕРЕРАБОТКИ ПОМЕТА

Алексей Владимирович Скляр

ООО «Биг Дачмен», г. Москва, Российская Федерация

Николай Григорьевич Башкирцев

ПФ Шекснинская, п. Шексна Вологодская обл., Российская Федерация

Сергей Александрович Чистяков

ПФ Шекснинская, п. Шексна Вологодская обл., Российская Федерация

\section{Маргарита Викторовна Постнова}

Волгоградский государственный университет, г. Волгоград, Российская Федерация

Аннотация. Анализ работ птицеводческих фабрик по переработке помета свидетельствует о том, что технологическая причина заключается в комплексе объективных недостатков методов, используемых в настоящее время. В статье показано, что современные методы энергоутилизации помета и все альтернативные способы выработки биоудобрений из пометного сырья с технологией интенсифицированной термофилии не уступают всем существующим ни в чем, по капиталоемкости и эксплуатационным затратам превосходят альтернативную группу в разы, а энергометоды - на порядок.

Ключевые слова: птицеводческие хозяйства, помет. 
Ежегодный выход помета по птицефабрикам РФ составляет более 24 млн тонн. Треть из него является подстилочным пометом, остальное - нативной массой [2]. Практически решив вопросы импортозамещения птицеводческой продукции, отрасль правомерно ставит задачи расширения своих экспортных возможностей, поэтому утилизационные мощности птицеводческих хозяйств (ПХ) должны быть готовы к переработке увеличивающихся объемов побочной продукции - помета. Типовым решением задачи утилизации помета в ПХ была переработка его в удобрения путем традиционного компостирования, для чего в хозяйствах строились пометохранилища. Но архаичная схема не работала с нужным качеством и с интенсивностью, соответствующим быстрому нарастанию мощностей отрасли. Анализ показывает, что технологическая причина заключалась в комплексе объективных недостатков метода (малая производительность с переработкой партии сырья за 1-3 месяца, невозможность компостировать помет при низких температурах, высокая экологическая опасность с накоплением и работой с огромными массами помета на открытых пространствах с аэрогенным рассеиванием инфекций и загрязнением почвы и пр.) [3; 4]. Качество переработки страдало из-за того, что для надежной работы пометоуборщиков большинства батарей в хозяйствах по технологии в пометную массу подливалась вода и нативный помет попадал в пометохранилища с повышенной влажностью (более 78 \%), что делало компостирование нереальным [1; 5]. И все же главным в этом вопросе был организационно-экономический фактор: ПХ в большинстве не имели в нужных объемах пашню, а окружающие птицепредприятие растениеводческие хозяйства, как и сами птицеводы, не были экономически простимулированы: земледелы - на то, чтобы внедрять в первую очередь более экологичные биоудобрения из помета, а не химию, исключив при этом и загрязнения среды, а ПХ - на ввод биодобавок в пометные удобрения (с доплатой за их качество, а при некондиции попадая на неизбежные действенные штрафы). Не исправили положения и разработки:

a) технологий компостирования с ворошением сырья (ВИМ и др.) - все минусы тра- диционной биотермии здесь дополняются еще и неоднократными перевалками десятков тыс. тонн пометной массы с усилением инфицирования воздуха и почвы;

б) высокотемпературной сушки помета (в том числе переувлажненного), что крайне энергозатратно (0,24 тонн дизтоплива на тонну помета), это требует сложной системы очистки топочных газов и в целом экономически несостоятельно.

Технологии центрифугирования (Димитровоградская п/ф, обезвоживание до 46-49 \%) и химстерилизация помета (БашГАУ) - это лишь частные решения отдельных вопросов, составляющих комплексную проблему утилизации. Наиболее удачное технико-технологическое решение задачи переработки пометного сырья в биоудобрения было сделано на базе интенсификации режимов естественного компостирования в закрытых камерах (биоферментер - БФ) с оптимальными регулируемыми аэрацией, температурой, влажностью, кислотностью, соотношением азот/углерод и прочее, что позволяет: производительно компостировать сырье за 5 суток (вместо 1-3 месяцев), исключить загрязнения почвы и воздуха, работать неподконтрольно ФСЭТАН и Природнадзору, использовать не спецтехнику, а только серийное оборудование, минимизировать капитальные и эксплуатационные затраты, с набором камер обеспечивать высший уровень технологической надежности. Это результат того, что данная технология включает опыт зарубежного «FarmWay», доработки ВНИИМЗ и большое число предложений ПХ по результатам многолетних производственных проверок. Например, на птицефабрике «Шекснинская» специалистами хозяйства и поставщиками оборудования были скорректированы режимы аэрации, система приборного контроля, рецептура ферментных добавок и технология их внесения. Все это позволило выпускать высококачественное органическое удобрение «Биокомпост-ЭКОМ» (ТУ 9841-01656959-00), поставку которого специалисты службы ветеринарного надзора г. Москвы и области разрешили в том числе для садово-паркового комплекса Московского кремля. Вакуумная сушка помета (фирмы: «ABONO», «Дюнамис», «TATRUS») решает те же задачи, что и БФ, но с помощью более сложной «эксклюзивной» техники, и воп- 
рос целесообразности применения последней технологии после ее тестирования на производстве будет решаться сравнительной оценкой уровня капитальных и эксплуатационных затрат по вариантам.

Вопрос использования помета для обогрева помещений (биогаз - ВИЭСХ, БИАЭ, «Биг Дачмен», сжигание в котлах - ООО «Союз», Thermodyne T.Pvt Ltd, пиролиз - ГК «Цивилизация», АО «Технокомплекс») нужно проработать как вариант, поскольку это массовый возобновляемый вид топлива с теплотворностью на уровне, близком к торфу и бурым углям $(2,4 \ldots 3,3$ тыс. ккал/кг сух. вещества), и по экологическим причинам, так как с переработкой в топливо исключаются загрязнения окружающей среды. Даже если будут получены нужные технические средства использования его как топлива, надо учитывать, что вариантов сырья для биологических удобрений (вместо экологически менее приемлемой химии) на 80 млн га пашни в РВ пока дефицит. Разведанных залежей топлива в России достаточно - торфа 400 млн га, углей - 220 млрд тонн (из которых $70 \%$ - бурые) и разработаны они всего на $5 \%$. Кроме того, надо отметить, что все три названные энерготехнологии требуют капиталоемкой техники, реализующей сложный производственный процесс, который во многом еще дорабатывается зарубежными и отечественными компаниями и НИИ:

а) анаэробное сбраживание птичьего помета в метатэнках из-за высокой концентрации аммонийных соединений в сырье требует двухстадийного реактора или смешивания нативного помета со значительным количеством наполнителя (до 85-90 \%: силос, свекловичный жом). Наполнители - дорогой корм и редкий материал - переводят данный способ в разряд локальных решений, которые нельзя использовать повсеместно;

б) варианты котлов на помете, например, типа УТПУ-МТ/ТЯ продолжительное время совершенствовались в ПХ ООО «Ассортимент» (при ВНИТИП) с целью дожига аэрозолей в топочных газах, чтобы исключить их налипание на экран, но нужный результат не был получен;

в) пиролиз помета относительно пунктов a) и б) - это более поздние работы, опыт испытаний таких установок в ПХ не публиковался и потому данный способ должен быть апробирован на производстве.

В качестве заключения: сравнивая названые методы энергоутилизации помета и все альтернативные способы выработки биоудобрений из пометного сырья с технологией интенсифицированной термофилии, надо особо выделить: не уступая всем им по капиталоемкости и эксплуатационным затратам, она превосходит альтернативную группу в разы, а энергометоды - на порядок.

\section{СПИСОК ЛИТЕРАТУРЫ}

1. Голубов, И. И. Методология формирования факторов производства птичьего помета / И. И. Голубов // Международный технико-экономический журнал. - 2016. - № 1. - С. 51-60.

2. Голубов, И. И. Основные факторы производства птичьего помета на птицефабриках / И. И. Голубов // Международный научный журнал. - 2016. № 1. - C. 41-46.

3. Мишуров, Н. П. Инновационные технологии подготовки птичьего помета к использованию / Н. П. Мишуров // Вестник Всероссийского научно-исследовательского института механизации животноводства. -2015 . - № 4 (20). - С. 106-114.

4. Миронов, В. В. Экобиотехнологии переработки органических отходов / В. В. Миронов // Вестник Всероссийского научно-исследовательского института механизации животноводства. - 2018. № 1 (29). - С. 60-65.

5. Теучеж, А. А. Применение птичьего помета в качестве органического удобрения / А. А. Теучеж // Политематический сетевой электронный научный журнал Кубанского государственного аграрного университета. - 2017. - № 128. - С. 914-931. 


\section{Information about the Authors}

Aleksey V. Sklyar, Big Dutchman Ltd., Moscow, Russian Federation.

Nikolay G. Bashkirtsev, Sheksninskaya Poultry Farm, Sheksna Village, Vologda Region, Russian Federation.

Sergey A. Chistyakov, Sheksninskaya Poultry Farm, Sheksna Village, Vologda Region, Russian Federation.

Margarita V. Postnova, Doctor of Sciences (Biology), Senior Researcher, Head of Department of Bioengineering and Bioinformatics, Volgograd State University, Prosp. Universitetsky, 100, 400062 Volgograd, Russian Federation, postnova@volsu.ru, biobio@volsu.ru.

\section{Информация об авторах}

Алексей Владимирович Скляр, ООО «Биг Дачмен», г. Москва, Российская Федерация.

Николай Григорьевич Башкирцев, ПФ Шекснинская, п. Шексна Вологодской области, Российская Федерация.

Сергей Александрович Чистяков, ПФ Шекснинская, п. Шексна Вологодской области, Российская Федерация.

Маргарита Викторовна Постнова, доктор биологических наук, старший научный сотрудник, заведующая кафедрой биоинженерии и биоинформатики, Волгоградский государственный университет, просп. Университетский, 100, 400062 г. Волгоград, Российская Федерация, postnova@volsu.ru, biobio@volsu.ru. 